Kumawula, Vol. 1, No.3, Desember 2018, Hal 170 - 182 DOI:http://10.24198/kumawula.v1i3.20948 ISSN 2620-844X (online)

Tersedia online di http://jurnal.unpad.ac.id/kumawula/index

\title{
IMPLEMENTASI SISTEM INFORMASI APLIKASI PENDIDIKAN (SIAP) TERHADAP PELAYANAN PUBLIK DI DINAS PENDIDIKAN DAN KEBUDAYAAN KOTA SERANG
}

\author{
Sopyan Syuri, Riswanda, Rd. Nia Kania Kurniawati, Ipah Ema Jumiati \\ Prodi Administrasi Publik, Fakultas IImu Sosial dan Ilmu Politik, Universitas Tirtayasa Agung \\ dr.riswanda@gmail.com
}

\begin{abstract}
A computer-based service could be a measure of information-technology. The City of Serang Government adopted the principle of 'e-governance' to measure the success of its public sector management. Educational Management Information System Apps (so-called SIAP) reflects the government efforts to come up with an up-to-date Apps in terms of providing services in education. The Apps, nevertheless, must cope with some remaining user-based issues. This research indicated that user issues existed due to the capacity of the Apps to ensure ease of use for users when seeking data by visiting either the website or when using the SIAP. The research approach was qualitative and aimed at measuring the web-based service quality. Cluster sampling was conducted to all populations of the Apps in Serang City to test out gaps between users' perceptions and users' expectations of the provided service. 'Webqual' was used as an analystical framework. The results indicated gaps within two domineering aspects, namely the 'quality of information' $(96,25)$ and the 'quality of interactions', whilst the 'functionality' aspect remained high (94.04).
\end{abstract}

Keywords: Education, Public, web

\section{Pendahuluan}

Aplikasi E-Governance secara umum adalah Tipe G-to-C (governance to citizens), yaitu di mana pemerintah membangun dan menerapkan berbagai portofolio teknologi informasi dengan tujuan utama untuk memperbaiki hubungan interaksi dengan masyarakat (rakyat). Dengan kata lain, tujuan dari dibangun aplikasi E- Governance; bertipe G-to-C adalah untuk mendekatkan pemerintah dengan rakyatnya melalui kanal-kanal akses yang beragam agar masyarakat dapat dengan mudah menjangkau pemerintahannya untuk pemenuhan berbagai kebutuhan pelayanan publik yang diperlukan dan memudahkan aparatur dalam melakukan pelayanan kepada masyarakat. Dinas Pendidikan dan Kebudayaan Kota Serang berupaya untuk mengembangkan potensi yang dimiliki, Potensi tersebut dituangkan dalam bentuk website Sistem Informasi Aplikasi Pendidikan (SIAP). Sistem Informasi Aplikasi Pendidikan (SIAP) dibentuk untuk menginformasikan tentang informasi data dinas, data siswa, data orang tua, dan data nilai siswa. Dukungan teknologi informasi pada Dinas Pendidikan dan Kebudayaan Kota Serang sangat penting untuk memberikan layanan secara cepat dan aman dalam proses 
pembuatan, pengurusan, pendaftaran dan yang bersangkutan dengan masalah pendidikan. Prinsip-prinsip yang memberikan dukungan tersebut, melalui rancang bangun, alur data dan proses akhir pada pelaksanaan kemudian dibuat dan dikembangkanlah Sistem Informasi Aplikasi Pendidikan (SIAP).

Pelayanan Sistem Informasi Aplikasi Pendidikan (SIAP) sudah diterapkan tetapi pelaksanaannya belum optimal, karena masih mengalami kendala terhadap penyampaian informasi kepada masyarakat. Kendala tersebut merupakan kecenderungan masyarakat untuk menanyakan secara langsung kepada aparatur yang bersangkutan tentang apa saja pelayanan yang ada di Dinas Pendidikan dan Kebudayaan Kota Serang tersebut. Masyarakat yang akan mengurus urusan tentang pendidikan, misalnya di bidang informasi pendaftaran, informasi dinas, informasi siswa, informasi orang tua, dan informasi nilai. Kebanyakan masyarakat menanyakan langsung tentang persyaratan yang harus dipenuhi padahal persyaratan tersebut telah tersedia dalam Sistem Informasi Aplikasi Pendidikan (SIAP ${ }^{1}$ ).

Berdasarkan data yang diperoleh dari Kantor Dinas Pendidikan dan Kebudayaan Kota Serang, jumlah pengunjung website Sistem Informasi Aplikasi Pendidikan (SIAP) Dinas Pendidikan dan Kebudayaan Kota Serang pada tahun dalam 3 (tiga) tahun terakhir mengalami peningkatan yang cukup signifikan dari tahun ke tahun (dengan IP adress yang berbeda). Hal tersebut menunjukkan penigkatan minat masyarakat terhadap website Sistem Informasi Aplikasi Pendidikan (SIAP) Dinas Pendidikan dan Kebudayaan Kota Serang dalam pencarian data dan informasi.

Tabel 1.1. Jumlah Pengunjung Website Sistem Informasi Aplikasi Pendidikan (SIAP)
\begin{tabular}{|c|c|c|c|}
\hline \multirow{2}{*}{ Dinas Pendidikan dan Kebudayaan Kota Serang } \\
\cline { 2 - 5 } & 2014 & 2015 & 2016 \\
\hline$[1]$ & {$[2]$} & {$[3]$} & {$[4]$} \\
\hline 1. Januari & 2.391 & 2.662 & 2.569 \\
\hline 2. Februari & 2.473 & 2.715 & 917 \\
\hline 3. Maret & 3.140 & 3.273 & 3.182 \\
\hline
\end{tabular}

\footnotetext{
${ }^{1}$ Sistem Informasi Aplikasi Pendidikan (SIAP) adalah suatu sistem untuk memfasilitasi pelayanan publik dalam memberikan informasi, mewujudkan efisiensi dan efektifitas pelayanan publik. Sistem Informasi Aplikasi Pendidikan (SIAP) diharapkan dapat memberikan pelayanan dalam meningkatkan produktivitas dan pelaksanaan kebijakan. Sistem Informasi Aplikasi Pendidikan (SIAP) dalam implementasinya terdiri dari adanya komponen yang berupa aplikasi informasi, aplikasi pendidikan dengan menggunakan sistem komputer yang memberikan berbagai informasi aplikasi pendidikan. Lingkungan Dinas Pendidikan dan Kebudayaan Kota Serang dalam memberikan pelayanan publiknya sudah menerapkan pelayanan melalui Sistem Informasi Aplikasi Pendidikan (SIAP).
} 


\begin{tabular}{|l|c|c|c|}
\hline 4. April & 2.811 & 3.112 & 3.197 \\
\hline 5. Mei & 2.666 & 3.012 & 4.080 \\
\hline 6. Juni & 2.190 & 2.642 & 3.321 \\
\hline 7. Juli & 1.276 & 1.565 & 2.546 \\
\hline 8. Agustus & 1.568 & 1.409 & 3.206 \\
\hline 9. September & 2.375 & 2.057 & 3.720 \\
\hline 10. Oktober & 2.836 & 2.385 & 4.755 \\
\hline 11. November & 2.822 & 2.925 & 4.440 \\
\hline 12. Desember & 2.093 & 2.324 & 3.857 \\
\hline Jumlah & $\mathbf{2 8 . 6 4 1}$ & $\mathbf{3 0 . 0 8 1}$ & $\mathbf{3 9 . 7 9 0}$ \\
\hline
\end{tabular}

Sumber : Dinas Pendidikan dan Kebudayaan Kota Serang (2017)

\section{Dimensi Webqual 4.0}

Webqual disusun berdasarkan penelitian terdiri atas tiga dimensi area yaitu (Barnes dan Vidgen, 2002):

a. Kegunaan (Usability)

Meliputi kemudahan untuk dipelajari, kemudahan untuk dimengerti, kemudahan untuk ditelusuri, kemudahan untuk digunakan, sangat menarik, menampilkan bentuk visual yang menyenangkan, memiliki kompetensi yang baik, memberikan pengalaman baru yang menyenangkan.

b. Kualitas Informasi (Information Quality)

Meliputi hal-hal seperti informasi yang akurat, informasi yang bisa dipercaya, informasi yang up to date (terbaru), informasi yang sesuai dengan topik bahasan, informasi yang mudah dimengerti, informasi yang sangat detail, dan informasi yang disajikan dalam format desain yang sesuai.

c. Kualitas Interaksi (Interaction Quality)

Meliputi kemampuan memberi rasa aman saat transaksi, memiliki reputasi yang bagus, memudahkan komunikasi, menciptakan perasaan emosional yang lebih personal, memiliki kepercayaan dalam menyimpan informasi pribadi pengguna, mampu menciptakan komunitas yang lebih spesifik, mampu memberi keyakinan bahwa janji yang disampaikan akan ditepati.

\section{Pendekatan Metodologis}

Jenis penelitian yang digunakan adalah metode penelitian survey dengan pendekatan cross sectional, dimana penelitian dilakukan pada suatu populasi, namun data yang dipelajari adalah dari sampel yang diambil dari populasi tersebut. Pendekatan cross sectional dilakukan untuk mengobservasi variabel-variabel pada waktu yang sama, dan subyek yang diamati hanya diobservasi sekali saja. Menurut tujuannya penelitian ini termasuk dalam penelitian terapan, dimana menerapkan sebuah model dalam menganalisis suatu masalah. Penelitian ini ditujukan 
untuk menganalisis kualitas pelayanan website SIAP Dinas Pendidikan dan Kebudayaan Kota Serang dengan menggunakan model webqual 4.0. Penggunaan model ini didasarkan pertimbangan bahwa sampai saat ini model webqual 4.0 diakui sebagai model "terbaik" untuk mengukur kualitas layanan website. Webqual 4.0 terdiri dari tiga dimensi inti yang mewakili kualitas suatu website, yaitu usability quality, information quality, dan service interaction quality, yang mengacu pada berbagai penelitian mengenai sistem informasi, penelitian mengenai kualitas layanan marketing, e-commerce, dan penelitian dalam bidang HumanComputer Interaction (HCI) dan web usability. Lokasi penelitian dikhususkan pada kantor Dinas Pendidikan dan Kebudayaan Kota Serang yang beralamat di Jalan Ki Ajurum Kelurahan Cipocok Jaya Kota Serang, Banten. Populasi termasuk semua pengunjung website SIAP Dinas Pendidikan dan Kebudayaan Kota Serang yang sudah terdaftar diantaranya pendidik/tenaga kependidikan yang sudah mempunyai NUPTK dan Peg ID serta orang tua/siswa yang diberikan akses untuk masuk dengan menggunakan Nomor Induk Siswa Nasional (NISN). Sampel dari penelitian ini adalah sebagian dari populasi yang diambil sebagai sumber data yaitu pengguna website SIAP Dinas Pendidikan dan Kebudayaan Kota Serang yang sudah terdaftar dan diberikan akses untuk masuk dalam website yang berkunjung ke Kantor Dinas Pendidikan dan Kebudayaan Kota Serang melalui Pelayanan Terpadu (PT) selama periode bulan Mei dan Juni 2018. Teknik pengambilan sampel ditentukan dengan Cluster Sampling yaitu tidak untuk sampel individu, akan tetapi digunakan untuk populasi yang berkelompok. Besarnya sampel adalah sebagai berikut:

a. Guru SMPN di kota serang $=659$ orang

b. Orang tua siswa yang mendaftar pada sekolah favorit di kota serang yaitu :

- SMP Negeri 1 Kota Serang

$=9$ Rombel

- $\quad$ SMP Negeri 2 Kota Serang

$=10$ Rombel

- SMP Negeri 4 Kota Serang

$=8$ Rombel

- $\quad$ SMP Negeri 7 Kota Serang

$=8$ Rombel

- $\quad$ SMP Negeri 13 Kota Serang

$=8$ Rombel

- $\quad$ SMP Negeri 14 Kota Serang

$=8$ Rombel

- $\quad$ SMP Negeri 15 Kota Serang

$=9$ Rombel

Jumlah total rombel

$=60$ rombel $\times 30$ orang

$=1.800$ orang

Maka sampel-nya adalah

a. Guru PNS SMPN se kota serang = 659 orang

b. Orang tua siswa pengguna layanan $=1.800$ orang

Jumlah total populasi

$=2.459$ orang

$$
\begin{aligned}
& \mathrm{n}=\frac{N}{1+N . e^{2}} \quad \mathrm{n}=\frac{2.459}{1+2.459 .0 .1^{2}} \quad \mathrm{n}=\frac{2.459}{1+2.459 .0 .01} \\
& \mathrm{n}=\frac{2.459}{25.59} \quad \mathbf{n}=\mathbf{9 6 . 0 9} \approx 96 \text { responden }
\end{aligned}
$$


jadi sampel yang digunakan dalam penelitian ini adalah 189 orang terdiri dari :

a. Guru PNS SMPN se Kota Serang $659: 2,459$ x $96=25.72 \approx 26$

b. Orang tua pengguna layanan $1.800: 2,459 \times 96=70.27 \approx 70$

\section{Tingkat presisi/sampling eror yang ditentukan adalah $10 \%$}

\section{Alur Olah Data}

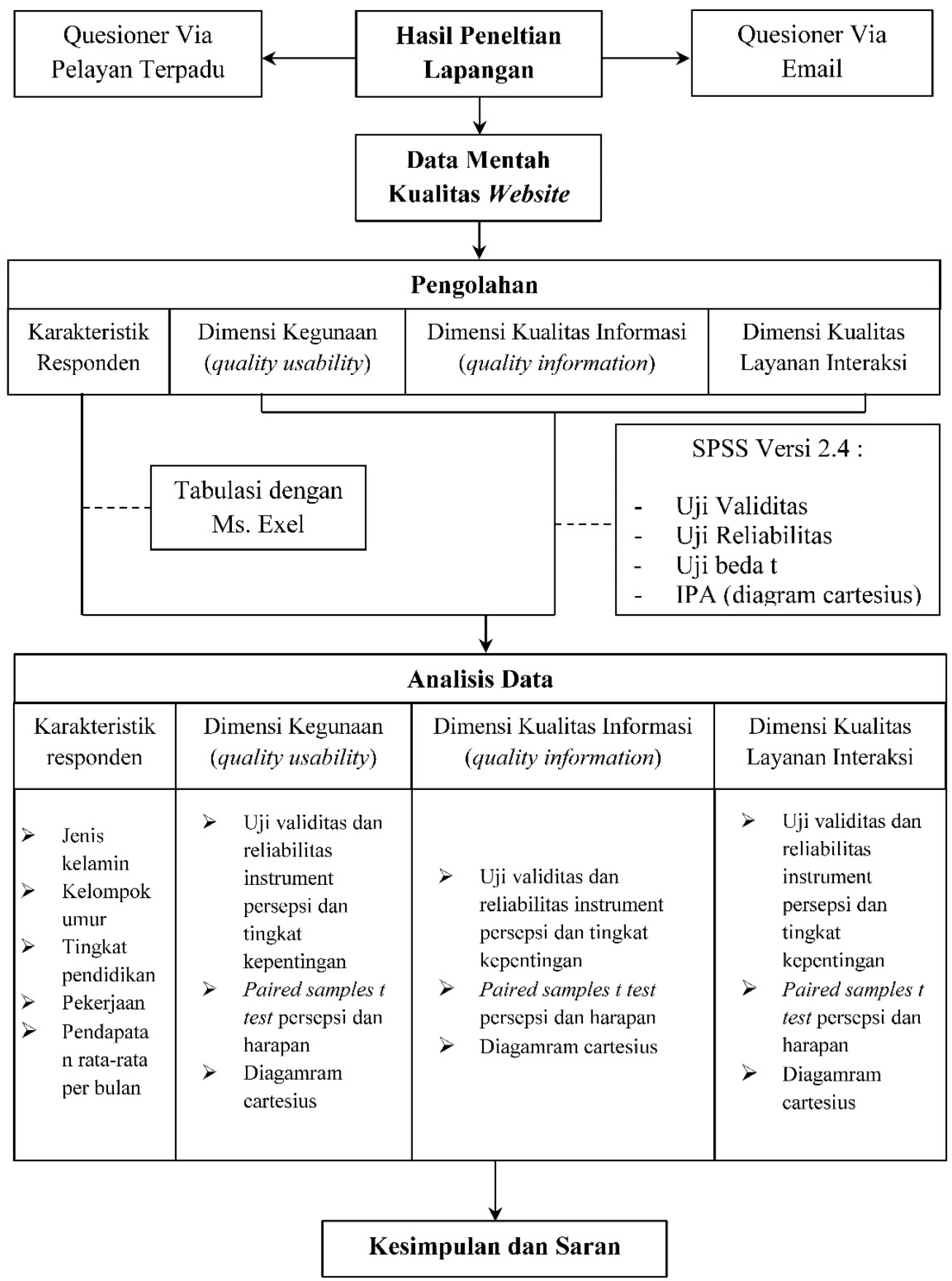




\section{Pembahasan}

\section{Dimensi Kegunaan (Usability)}

Frekuensi jawaban responden menurut persepsi terhadap dimensi kegunaan (usability) dapat dilihat pada Tabel 1:

Tabel 1 Frekuensi Jawaban Responden Menurut Tingkat Kepentingan per Atribut Terhadap Dimensi Kegunaan (Usability)

\begin{tabular}{|c|c|c|c|c|c|c|c|}
\hline \multirow{2}{*}{ No } & \multirow{2}{*}{ Atribut } & \multicolumn{4}{|c|}{ Frekuensi Jawaban } & \multirow{2}{*}{$\begin{array}{l}\text { Total } \\
\text { Skor }\end{array}$} & \multirow{2}{*}{$\begin{array}{l}\text { Rata- } \\
\text { rata }\end{array}$} \\
\hline & & STS & TS & $\mathrm{S}$ & SS & & \\
\hline 1 & $\begin{array}{l}\text { Saya merasa mudah untuk } \\
\text { bernavigasi dalam website SIAP }\end{array}$ & - & 2 & 62 & 32 & 318 & 3.31 \\
\hline 2 & $\begin{array}{l}\text { Cara penggunaan website SIAP } \\
\text { mudah dimengerti }\end{array}$ & - & 10 & 56 & 30 & 308 & 3.21 \\
\hline 3 & $\begin{array}{l}\text { Saya merasa desain tampilan } \\
\text { website SIAP cukup menarik }\end{array}$ & - & 2 & 82 & 12 & 298 & 3.10 \\
\hline 4 & $\begin{array}{l}\text { Saya merasa tertarik menggunakan } \\
\text { website SIAP karena informasi yang } \\
\text { tersedia di sana }\end{array}$ & - & 4 & 49 & 43 & 327 & 3.41 \\
\hline 5 & $\begin{array}{l}\text { Saya merasa mudah untuk } \\
\text { mempelajari cara pengoperasian } \\
\text { website SIAP }\end{array}$ & - & - & 42 & 54 & 342 & 3.56 \\
\hline 6 & $\begin{array}{l}\text { Saya merasa pengoperasian website } \\
\text { SIAP cukup jelas }\end{array}$ & - & 3 & 63 & 30 & 315 & 3.28 \\
\hline 7 & $\begin{array}{l}\text { Saya menemukan pengalaman baru } \\
\text { yang menyenangkan yang hanya ada } \\
\text { di website SIAP }\end{array}$ & - & - & 75 & 21 & 309 & 3.22 \\
\hline 8 & $\begin{array}{l}\text { Menurut saya, website SIAP } \\
\text { memiliki data yang kompeten }\end{array}$ & - & 2 & 53 & 14 & 327 & 3.41 \\
\hline & Dimensi Kegunaan (Usability) & & 23 & 482 & 263 & 2575 & 3.31 \\
\hline
\end{tabular}

Sumber: Data Penelitian (diolah)

Dari penjelasan di atas, kemudahan untuk mengoperasikan website SIAP cukup jelas menjadi atribut yang dianggap paling penting oleh responden pada dimensi kegunaan (usability) selain itu juga alamat website Dinas Pendidikan dan Kebudayaan Kota Serang tidak kalah penting dalam dimensi kegunaan. Harapan tersebut nampaknya telah terealisasi dengan munculnya alamat website Dinas Pendidikan dan Kebudayaan Kota Serang pada urutan pertama pada saat peneliti memasukkan beberapa kata kunci pencarian menggunakan situs pencari google.com yang diakses pada tanggal 02 November 2017. 


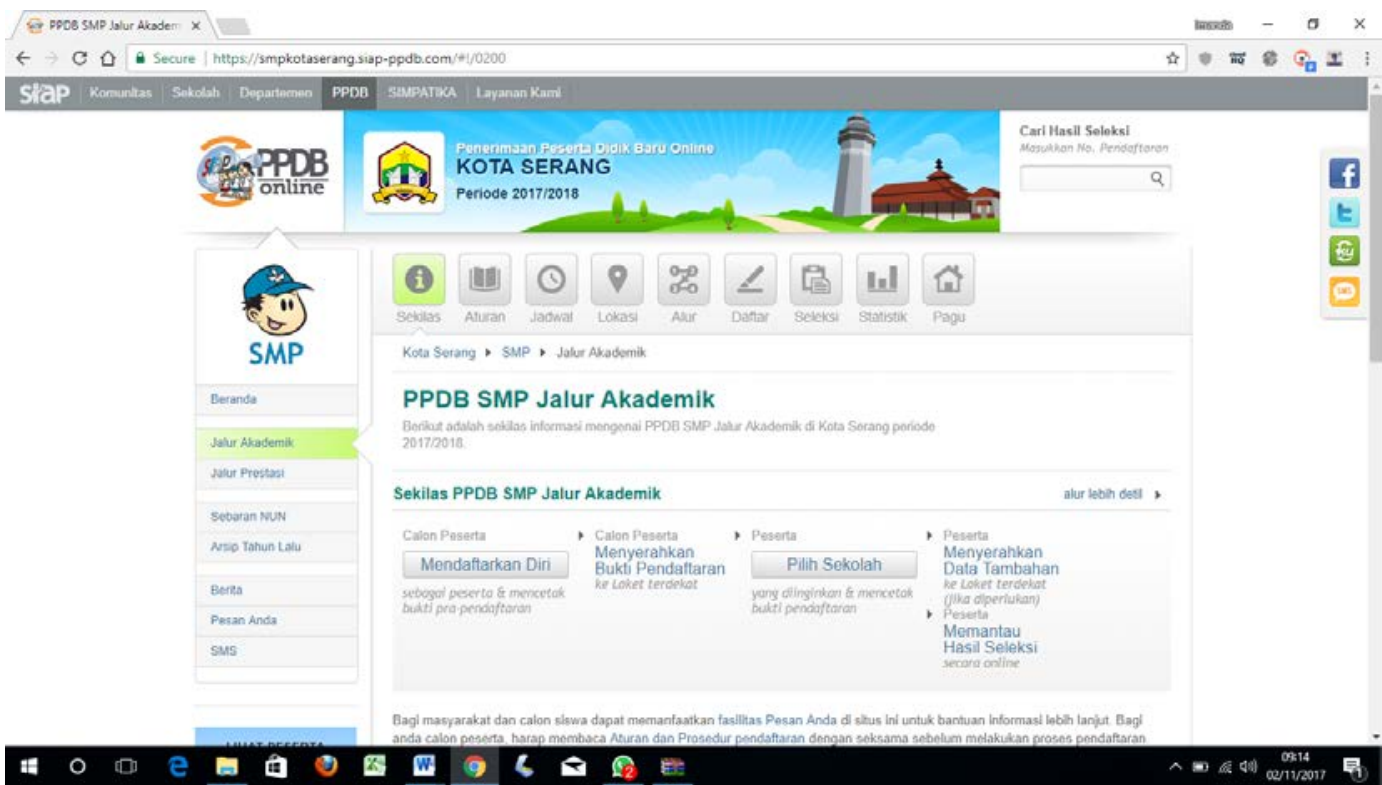

Gambar 1. Hasil Pencarian Website SIAP PPDB Online Dinas Pendidikan dan Kebudayaan Kota Serang Pada Situs google.com

\section{Dimensi Kualitas Informasi (Information Quality)}

Frekuensi jawaban responden menurut tingkat harapan per atribut terhadap dimensi kualitas informasi (information quality). Dari tabel tersebut dapat diketahui bahwa total skor tertinggi tingkat harapan menurut responden pada dimensi kualitas informasi (information quality) ada pada atribut "Menurut saya, website SIAP menyajikan informasi dalam format yang sesuai” yaitu total skor 348 dengan rincian sebanyak 36 responden menjawab setuju (S) dan 60 responden menjawab sangat setuju (SS). Sementara itu, skor terendah tingkat kepentingan per atribut responden pada dimensi kualitas informasi (information quality) ada pada atribut "Menurut saya, data yang tersedia di website SIAP sudah cukup update” yaitu total skor 324 dengan rincian sebanyak 8 responden menjawab tidak setuju (TS), 44 responden menjawab setuju (S) dan 44 responden sangat setuju (SS). Secara total, dimensi kualitas informasi (information quality) mendapat skor tingkat kepentingan menurut responden sebesar 3.336 dengan rata-rata 3,48 (setuju). Dengan rata-rata jawaban responden per atribut lebih besar dari 3, dapat disimpulkan bahwa secara umum atribut pada dimensi kualitas informasi (information quality) dianggap penting oleh responden. Secara lengkap, skor tingkat harapan per atribut dimensi kualitas informasi (information quality): 
Tabel 2. Frekuensi Jawaban Responden Menurut Tingkat Kepentingan per Atribut Terhadap Dimensi Kualitas Informasi (Information Quality)

\begin{tabular}{|c|c|c|c|c|c|c|c|}
\hline \multirow{2}{*}{ No } & \multirow{2}{*}{ Atribut } & \multicolumn{4}{|c|}{ Frekuensi Jawaban } & \multirow{2}{*}{$\begin{array}{l}\text { Total } \\
\text { Skor }\end{array}$} & \multirow{2}{*}{$\begin{array}{l}\text { Rata- } \\
\text { rata }\end{array}$} \\
\hline & & STS & TS & $\mathrm{S}$ & SS & & \\
\hline 1 & $\begin{array}{l}\text { Saya merasa website SIAP sudah } \\
\text { menyediakan informasi yang akurat }\end{array}$ & - & 3 & 32 & 61 & 346 & 3.60 \\
\hline 2 & $\begin{array}{l}\text { Saya merasa website SIAP } \\
\text { memberikan informasi yang dapat } \\
\text { dipercaya }\end{array}$ & - & - & 42 & 54 & 342 & 3.56 \\
\hline 3 & $\begin{array}{l}\text { Menurut saya, data yang tersedia di } \\
\text { website SIAP sudah cukup update }\end{array}$ & - & 8 & 44 & 44 & 324 & 3.38 \\
\hline 4 & $\begin{array}{l}\text { Menurut saya, data yang disajikan } \\
\text { dalam website SIAP cukup } \\
\text { akuntabel }\end{array}$ & - & - & 59 & 37 & 325 & 3.39 \\
\hline 5 & $\begin{array}{l}\text { Website SIAP menyediakan } \\
\text { informasi yang relevan }\end{array}$ & - & 2 & 52 & 42 & 328 & 3.42 \\
\hline 6 & $\begin{array}{l}\text { Website SIAP menyajikan informasi } \\
\text { yang terkait dengan fungsi Dinas } \\
\text { Pendidikan dan Kebudayaan }\end{array}$ & - & - & 59 & 37 & 325 & 3.39 \\
\hline 7 & $\begin{array}{l}\text { Menurut saya, website SIAP } \\
\text { menyediakan informasi yang mudah } \\
\text { dimengerti }\end{array}$ & - & - & 53 & 43 & 331 & 3.45 \\
\hline 8 & $\begin{array}{l}\text { Saya merasa informasi yang } \\
\text { disediakan website SIAP cukup } \\
\text { detail }\end{array}$ & - & - & 56 & 40 & 328 & 3.42 \\
\hline 9 & $\begin{array}{l}\text { Menurut saya, website SIAP } \\
\text { menyajikan informasi dalam format } \\
\text { yang sesuai }\end{array}$ & - & - & 36 & 60 & 348 & 3.63 \\
\hline 10 & $\begin{array}{l}\text { Saya merasa informasi di website } \\
\text { SIAP sudah dikemas dengan } \\
\text { tampilan yang sesuai dengan jenis } \\
\text { informasinya }\end{array}$ & - & - & 45 & 51 & 339 & 3.53 \\
\hline & $\begin{array}{l}\text { Dimensi Kualitas Informasi } \\
\text { (Information Quality) }\end{array}$ & - & 13 & 478 & 469 & 3336 & 3.48 \\
\hline
\end{tabular}

Sumber: Data Penelitian (diolah)

Aspek kemudahan dalam melakukan akses masuk (login) oleh pengguna layanan website SIAP menjadi hal yang sangat penting bagi Dinas Pendidikan dan Kebudayaan Kota Serang sebagai lembaga pemerintah yang bertugas sebagai penyedia layanan pendidikan. Dalam website SIAP Dinas Pendidikan dan Kebudayaan Kota Serang, terdapat kolom yang harus diisi dengan menggunakan Nomor Unik Pendidik Tenaga Kependidikan yang bertujuan agar pengunjung dapat melakukan akses masuk dengan mudah walaupun hanya 
dengan mengisi kotak akun dan pasword. Gambar berikut merupakan tampilan Login dalam website SIAP Dinas Pendidikan dan Kebudayaan Kota Serang.

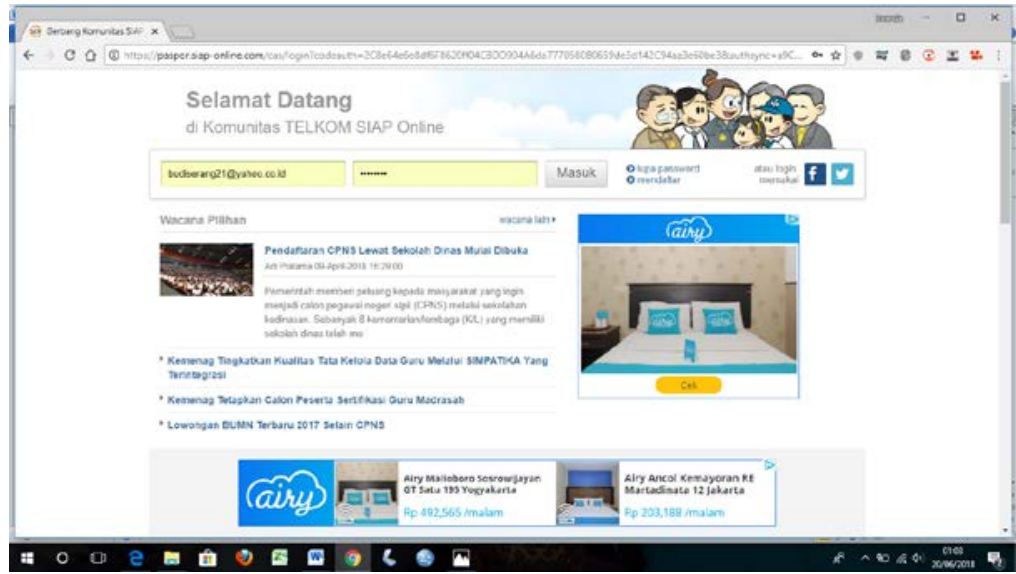

Gambar 2. Tampilan Login Website SIAP Dinas Pendidikan dan Kebudayaan Kota Serang

Sumber: Dinas Pendidikan dan Kebudayaan Kota Serang (2017)

\section{Dimensi Kualitas Interaksi Layanan (Service Interaction Quality)}

Frekuensi jawaban responden menurut tingkat kepentingan per atribut terhadap dimensi kualitas interaksi layanan (service interaction quality). Dari tabel tersebut dapat diketahui bahwa total skor tertinggi tingkat kepentingan menurut responden pada dimensi kualitas interaksi layanan (service interaction quality) ada pada atribut "Saya percaya bahwa layanan yang didapat melalui Website SIAP sudah sesuai dengan yang dijanjikan” yaitu total skor 323 dengan rincian sebanyak 61 responden menjawab setuju (S) dan 35 responden menjawab sangat setuju (SS). Sementara itu, skor terendah tingkat kepentingan per atribut responden pada dimensi kualitas interaksi layanan (service interaction quality) ada pada atribut "Saya merasa informasi pribadi saya terjaga saat menggunakan website SIAP” yaitu total skor 287 dengan rincian sebanyak 16 responden menjawab tidak setuju (TS), 65 responden menjawab setuju (S) dan 15 responden sangat setuju (SS). Secara total, dimensi kualitas interaksi layanan (service interaction quality) mendapat skor tingkat kepentingan menurut responden sebesar 2.440 dengan rata-rata 3,18 (penting). Dengan rata-rata jawaban responden per atribut lebih besar dari 3, dapat disimpulkan bahwa secara umum atribut pada dimensi kualitas interaksi layanan (service interaction quality) dianggap penting oleh responden. Secara lengkap, skor tingkat kepentingan per atribut dimensi kualitas interaksi layanan (service interaction quality) dapat dilihat pada Tabel 4.10. 
Tabel 3 Frekuensi Jawaban Responden Menurut Tingkat Kepentingan per Atribut Terhadap Dimensi Kualitas Interaksi Layanan

(Service Interaction Quality)

\begin{tabular}{|c|c|c|c|c|c|c|c|}
\hline \multirow{2}{*}{ No } & \multirow{2}{*}{ Atribut } & \multicolumn{4}{|c|}{ Frekuensi Jawaban } & \multirow{2}{*}{$\begin{array}{l}\text { Total } \\
\text { Skor }\end{array}$} & \multirow{2}{*}{$\begin{array}{l}\text { Rata- } \\
\text { rata }\end{array}$} \\
\hline & & STS & TS & $\mathrm{S}$ & SS & & \\
\hline 1 & $\begin{array}{l}\text { Menurut saya, website SIAP } \\
\text { memiliki reputasi yang baik }\end{array}$ & - & - & 69 & 27 & 315 & 3.28 \\
\hline 2 & $\begin{array}{l}\text { Saya merasa aman saat } \\
\text { menggunakan website SIAP }\end{array}$ & - & 11 & 63 & 22 & 299 & 3.11 \\
\hline 3 & $\begin{array}{l}\text { Saya merasa website SIAP dapat } \\
\text { mendukung terbentuknya komunitas } \\
\text { sesama pengguna website SIAP }\end{array}$ & - & 3 & 69 & 24 & 309 & 3.22 \\
\hline 4 & $\begin{array}{l}\text { Website SIAP memudahkan saya } \\
\text { berkomunikasi dengan Dinas } \\
\text { Pendidikan dan Kebudayaan Kota } \\
\text { Serang }\end{array}$ & - & 23 & 50 & 23 & 288 & 3.00 \\
\hline 5 & $\begin{array}{l}\text { Saya merasa informasi pribadi saya } \\
\text { terjaga saat menggunakan website } \\
\text { SIAP }\end{array}$ & - & 16 & 65 & 15 & 287 & 2.99 \\
\hline 6 & $\begin{array}{l}\text { Saya percaya bahwa layanan yang } \\
\text { didapat melalui Website SIAP sudah } \\
\text { sesuai dengan yang dijanjikan }\end{array}$ & - & 0 & 61 & 35 & 323 & 3.36 \\
\hline 7 & $\begin{array}{l}\text { Saya merasa website SIAP dapat } \\
\text { dipercaya }\end{array}$ & - & 2 & 69 & 25 & 311 & 3.24 \\
\hline 8 & $\begin{array}{l}\text { Menurut saya, website SIAP } \\
\text { memperhatikan kebutuhan } \\
\text { emosional dari masing-masing } \\
\text { penggunanya }\end{array}$ & - & 6 & 64 & 26 & 308 & 3.21 \\
\hline & $\begin{array}{l}\text { mensi Kualitas Interaksi Layanan } \\
\text { (Service Interaction Quality) }\end{array}$ & - & 61 & 510 & 197 & 2440 & 3.18 \\
\hline
\end{tabular}

Layanan website SIAP Dinas pendidikan dan Kebudayaan Kota Serang untuk mengetahui layanan yang didapat oleh pengguna maka Dinas Pendidikan dan Kebudayaan Kota Serang selalu memberikan data atau format yang dijanjikan/dijadwalkan oleh pengelola website SIAP, seperti hal nya pengumuman pada penerimaan peserta didik baru secara online, hasil pengumumannya langsung ditampilkan dalam halaman website secara menyeluruh guna mewujudkan E-Governance. 


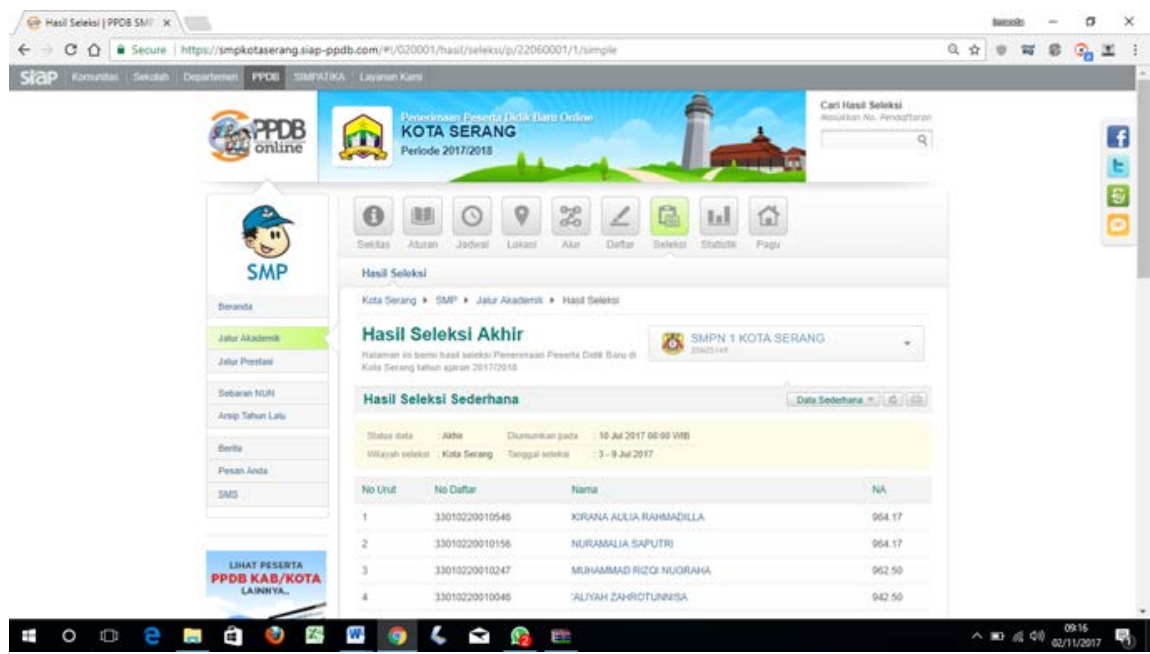

\section{Gambar 4. Tampilan pengumuman SIAP PPDB Online Dinas Pendidikan dan Kebudayaan Kota Serang}

Sumber: Dinas Pendidikan dan Kebudayaan Kota Serang (2017)

\section{Analisis Perbedaan}

Pengujian hipotesis dilakukan dengan teknik uji beda t (Paired Samples T Test). Hasil analisis terhadap dimensi kualitas informasi (information quality) dan dimensi kualitas interaksi layanan (service interaction quality) menunjukkan bahwa terdapat perbedaan ratarata antara persepsi aktual dan harapan ideal pada dua dimensi tersebut. Hal ini dibuktikan dari nilai signifikansi masing-masing yang sebesar 0,002 dan 0,039, atau nilai signifikansi dari dua dimensi tersebut kurang dari 0,05. Artinya, perbedaan rata-rata antara persepsi dan harapan pengunjung website terhadap kualitas pelayanan website adalah signifikan. Sementara itu, hasil yang berbeda ditunjukkan pada dimensi kegunaan (usability) yang mempunyai nilai signifikansi sebesar 0,057 > 0,05 yang menunjukkan tidak ada perbedaan yang berarti antara persepsi aktual dan harapan ideal pengunjung website SIAP Dinas Pendidikan dan Kebudayaan Kota Serang pada dimensi tersebut. Artinya pada dimensi kegunaan (usability) pelayanan website Dinas Pendidikan dan Kebudayaan Kota Serang sudah dianggap baik kualitasnya oleh pengunjung website SIAP Dinas Pendidikan dan Kebudayaan Kota Serang.

Secara rinci hasil uji hipotesis dimensi kegunaan (usability), dimensi kualitas informasi (information quality) dan dimensi kualitas interaksi layanan (service interaction quality) menggunakan teknik uji beda t (Paired Samples T Test) ditampilkan dalam Tabel 4.11. 
Tabel 4.11. Hasil Uji Hipotesis

\begin{tabular}{|c|c|c|c|c|c|c|}
\hline \multicolumn{2}{|l|}{ Dimensi } & \multicolumn{2}{|c|}{ Mean } & $\stackrel{\mathrm{t}}{\text { hitung }}$ & Sig. & Ket. \\
\hline \multirow{2}{*}{$\begin{array}{l}\text { Kegunaan } \\
\text { (Usability) }\end{array}$} & Persepsi & 3,21 & \multirow{2}{*}{$-0,102$} & \multirow{2}{*}{$-1,847$} & \multirow{2}{*}{0,107} & \multirow{2}{*}{$\begin{array}{l}\text { TIDAK } \\
\text { BEDA }\end{array}$} \\
\hline & Harapan & 3,31 & & & & \\
\hline \multirow{2}{*}{$\begin{array}{l}\text { Kualitas Informasi } \\
\text { (Information Quality) }\end{array}$} & Persepsi & 3,34 & \multirow{2}{*}{$-0,136$} & \multirow{2}{*}{-4.168} & \multirow{2}{*}{0,002} & \multirow{2}{*}{$\begin{array}{r}\text { BEDA } \\
\text { NYATA }\end{array}$} \\
\hline & Harapan & 3,48 & & & & \\
\hline \multirow{2}{*}{$\begin{array}{l}\text { Kualitas Interaksi } \\
\text { Layanan } \\
\text { (Service Interaction } \\
\text { Quality) }\end{array}$} & Persepsi & 3,07 & \multirow[b]{2}{*}{$-0,106$} & \multirow[b]{2}{*}{-2.535} & \multirow[b]{2}{*}{0,039} & \multirow[b]{2}{*}{$\begin{array}{l}\text { BEDA } \\
\text { NYATA }\end{array}$} \\
\hline & Harapan & 3,18 & & & & \\
\hline
\end{tabular}

Sumber : Data Penelitian (diolah)

Simpulan hasil penelitian dapat disampaikan sebagai berikut:

1. Hasil penelitian menunjukkan bahwa kualitas pelayanan website Dinas Pendidikan dan Kebudayaan Kota Serang belum sepenuhnya memenuhi harapan pengunjung website. Hal ini terbukti dari adanya perbedaan mean antara persepsi aktual dengan harapan ideal pengunjung website SIAP terhadap dimensi kualitas informasi (information quality) dan dimensi kualitas interaksi layanan (service interaction quality) yang bernilai signifikansi 0,002 dan 0,039 (lebih kecil daripada 0,05). Sementara itu, pada dimensi kegunaan (usability) menunjukkan tidak ada perbedaan yang berarti antara persepsi aktual dan harapan ideal pengunjung website dibuktikan dengan nilai signifikansi 0,107 (lebih besar daripada 0,05). Artinya, pada dimensi kegunaan pelayanan website Dinas Pendidikan dan Kebudayaan Kota Serang sudah dianggap baik kualitasnya oleh pengunjung website SIAP.

2. Hasil penelitian menunjukkan bahwa semua gap bernilai negatif, dimana persepsi lebih kecil dibandingkan dengan harapan pengunjung website. Gap paling kecil terletak pada dimensi kegunaan (usability) dengan nilai selisih rata-rata sebesar -0,102 yang mengindikasikan bahwa layanan website Dinas Pendidikan dan Kebudayaan Kota Serang cukup berhasil pada dimensi tersebut. Gap paling besar terletak pada dimensi kualitas informasi (information quality) dengan nilai selisih rata-rata sebesar -0,136 yang mengindikasikan bahwa layanan website Dinas Pendidikan dan Kebudayaan Kota Serang belum memenuhi harapan ideal pengunjung website terutama dari kualitas informasi (information quality).

3. Hasil penelitian menunjukkan bahwa indikator merasa mudah untuk mempelajari cara pengoperasian website SIAP, website SIAP menyajikan informasi dalam format yang 
sesuai, dan website SIAP dapat mendukung terbentuknya komunitas sesama pengguna website SIAP merupakan prioritas utama untuk diadakan upaya perbaikan oleh pihak pengelola website SIAP Dinas Pendidikan dan Kebudayaan Kota Serang.

\section{Referensi}

Barnes, S., \& Vidgen, R (2002) WebQual: An Integrative Approach to the Assessment of ECommerce Quality, Journal of Electronic Commerce Research, vol. 3, no. 3

Dinas Pendidikan dan Kebudayaan Kota Serang (2017) Sistem Informasi Aplikasi Pendidikan, Dinas Pendidikan dan Kebudayaan Kota Serang 